\title{
Empirical Analysis of the Financial Performance of Listed Banks in Ghana
}

\author{
Joseph Kwasi Agyemang (Corresponding author) \\ Department of Accounting, Faculty of Commerce, University of Eswatini, Eswatini \\ E-mail: jagyemang@uniswa.sz
}

Barjoyai Bin Bardai

Department of Accounting, Faculty of Finance and Administrative Science

Al-Madinah International University, Malaysia

Samuel Ntoah-Boadi

Department of Accountancy, Sunyani Technical University, Ghana

Received: February 4, 2020

Accepted: February 27, 2020 Published: March 25, 2020

doi:10.5296/ijafr.v10i1.16748

URL: https://doi.org/10.5296/ijafr.v10i1. 16748

\begin{abstract}
Notwithstanding the challenges facing the financial markets and the current global economic growth prospects, the listed banks that are operating in healthy situation will remain resilient. The study sought to investigate the financial performance of listed Banks Ghana during the period of 2015 to 2018. Financial ratios were used to assess the financial performance (profitability), liquidity, credit performance and capital structure (capital adequacy). Bar charts and line graphs were used to analyse the panel data and the findings indicate that among ROA, ROE, ROD and NIM, net interest margin (NIM) is the best measure of profitability. The findings of the study also showed that the liquidity position of these banks is very alarming and aggravating as most the banks have poor liquidity issues making depositors vulnerable of losing their investments. The findings again revealed that the credit performance of the banks is very abysmal as a result of ineffective and inefficient credit assessments resulting in bad loans. In evaluating the capital adequacy ratio, it was evident that the banks were highly undercapitalised which vindicates the effort and the stringent
\end{abstract}


measures by bank of Ghana for its intensified regulations. This study suggests managerial and policy recommendations regarding the development and enhancing of some banking operations which will boost the banks' profitability, liquidity, credit performance and improve the capital adequacy challenge for the banks.

Keywords: Return on assets, Return on equity, Return on deposits, Profitability, Performance

\section{Introduction}

Evaluating the effectiveness of an economy cannot be accomplished without studying and given a particular attention to the assessment of the financial performance of its banks, (Haque \& Sharma, 2011). Therefore, the banking and financial industry has taken a centre stage in the recent study of Accounting and financial management, as it is witnessing a growing both in terms of the number of such institutions, or in terms of the amount of money managed by or diversity activities. In spite of this progress and successes achieved by the banking and financial institutions, the industry still has challenges which will require further intensive efforts on the part of these institutions. Such to enhance the quality of its products and services and diversity and to keep pace with the rapid developments taking place in the world in this field.

Casu et al. (2006) mentioned that financial institutions have received a lot of threats as a result of globalization, competition from nonbanking financial institutions, coupled with the rigorous banking regulations and the volatile market dynamic pressures. Interestingly, several banks and other financial institutions have made an attempt to establish new ways of improving services. The performance of entities can be measured by employing different ratios. The common measures that banks can use to assess performance are return on total assets (ROA) and return on total equity (ROE). Analysts have used these measures in assessing the performance of various entities in terms of forecasting trends and predicting corporate failure (Gilbert \& Wheelock, 2007).

Currently, studies focus more on accounting ratios instead of simple ratios such as ROE or ROA. Accounting ratios can be used to assess performance of banks in the area of assets, revenue, profit, market value, number of employees, investments, and customer (Seiford \& Zhu, 1999).

Ghanaian banks cannot operate in isolation, since they form part of a larger global banking industry and therefore must adopt strategies that will enhance their technical, operational and resource allocate efficiencies to make them compete better if they are to survive in the global competitive environment. There have been many banking crises across the globe from the early 1980s and onward, with many of them occurring in developing countries (Demirguc-Kunt \& Detragiache, 1998). According to their study, these crises were caused by inefficiencies in the operations of the banks, ranging from inadequate liquidity, excessive overhead cost, increased cost of funding due to undercapitalization and unhealthy loan portfolios arising from increased exposure to credit risk. A study undertaken by Bawumia et al. (2005) and Sarpong et al. (2013), indicated that there are inefficiencies in the Ghanaian banking industry in terms of credit risk reduction, service provision and cost management. 


\section{Macrothink}

International Journal of Accounting and Financial Reporting

ISSN 2162-3082

2020, Vol. 10, No. 1

In assessing the performance of entities, financial measures have always been used. Financial measures assess the entity in monetary terms and provide a high level of aggregate information. Financial measures are acceptable follow the rules of General Accepted Accounting Principles (Kani, 2017). Annor and Obeng (2017) have indicated that the assessment of the overall financial condition of an entity depends on the income statement and the statement of financial position.

Many studies have indicated that financial institutions and the banking sector have contributed enormously to the growth of a country (Harcourt, 2017). Other studies such as Kashyap \& Stein (2000) and Sarpong (2013) have also revealed that the banking and other financial institutions have failed many people and businesses as a result of an unexpected collapse and liquidation. Adam (2014) has mentioned that studies assessing the financial performance of banks have received less attention. Therefore, this study seeks to fill this gap by assessing the financial performance of listed banks in Ghana. This study will help to provide sensitive financial information to economists and business analysts to assist investors in making prudent investment decisions.

\subsection{Research Objective}

The main objective of this study is to assess the financial performance of the listed banks on the Ghana stock exchange. In order to achieve this objective, the following specific objectives were examined and analyzed.

i. To examine the key financial performance ratios of the listed banks in Ghana.

ii. To assess which performance measure (ratio) is the best measure of profitability of the listed banks in Ghana.

iii. To assess the liquidity performance of the listed banks in Ghana.

iv. To evaluate the credit performance of the listed banks in Ghana.

v. To examine the capital adequacy ratio (financial leverage) of the listed banks in Ghana.

\subsection{Research Questions}

The study would be guided by the following specific research questions in order to achieve the overall objective of the study.

i. What are the key financial performance indicators (ratios) of listed banks in Ghana?

ii. What is the best financial performance indicator (ratio) used in measuring the profitability of the listed banks in Ghana?

iii. What is the liquidity performance of the listed banks in Ghana?

iv. What is the credit performance of the listed banks in Ghana?

v. What is the capital adequacy ratio (financial leverage) of the listed banks in Ghana? 


\section{Theoretical Review}

\subsection{Market Power Theory}

The market power theories consist of the traditional industrial organization model embedded in the structure-conduct-performance theory. The Structure-Conduct-Performance (SCP) was first proposed by Bain (1951). The SCP approach argues that an industry's performance depends on the conduct of its firms, which then depends on the structure. Markets with high concentration level induce a firm to behave (conduct) in a collusive way, as a result, performance of the firms gets better (Goddard et al., 2004). Profits of the firms are determined by the concentration level of the market. Thus, the SCP theory explains that the market structure (concentration level of the market) through the conduct link determines the performance (profitability) of firms. In summary, SCP theory postulates that exogenous basic conditions determine the structure of the market and that there is a one-way causation flow from the market structure that is through conduct to performance. The traditional SCP theory has been challenged by the Relative Market Power (RMP).

The debate about the importance of the market share rather than the concentration as a criterion of the market power virtually started with Shepherd (1972) leading Rhoades (1997) to coin the phrase "relative market power" (Nissan,2003). RMP suggests that banks with large market shares and well-differentiated products are more efficient and can earn high profits. In other words, the banks with (relatively) large market share benefit from this exertion of market power, and independent of market concentration. This theory seeks to underpin this study since most listed banks in Ghana are strategically positioned in very high concentrated market segments. Again, some listed banks on the Ghana stock exchange have not even differentiated the total market at all and as result they are rather comfortable in serving the overall market instead.

\subsection{Efficient Structure Theory}

The efficient structure theory (ES) emerges from the criticism of the SCP theory by Demsetz (1973) and Peltzman (1977). The ES postulates that the relationship between the market structure and performance of any bank is defined by the efficiency of the bank. Banks with superior management or production technologies have lower costs and therefore higher profits. The idea of the efficiency theory is based on the fact that the more efficient banks incur lower costs, which may lead directly to higher profitability. The efficient structure theory has been proposed in two hypotheses, the Efficient-Structure-X-efficiency (ESX) and efficient-structure-scale-efficiency (ESS) hypotheses. In the ESX hypothesis, it states that banks with more efficiency (better management, technologies and practices control costs) have lower costs, higher profits and larger market share. The ESS hypothesis states that the difference in profitability between banks is not caused by differences in the quality of management, but by differences in the level of scale efficiency at which a bank is operating. In other words, the ESS hypothesis states that some banks achieve better scale of operation that leads to lower costs. Lower costs lead to higher profit and faster growth for the scale-efficient banks. The extent to which this theory supports this study cannot be over emphasised in the sense that most listed banks in Ghana seeks to be extremely prudent in 
their cost management strategies, and this awareness has led most of them to survive the most turbulence environment in the banking industry.

\subsection{Expense-Preference Theory}

The Expense-Preference behaviour theory is tested in the performance of banks, see for example: Haron (1997) and Al Manaseer (2007). It was first introduced by Becker (1957) and further developed by Williamson (1963). The Expense-Preference theory provides an alternative view regarding managerial behaviours. It proposes that the main goal which managers pursue is not to maximise profit but to own the utility or utility of the firm (bank), which is usually achieved via increasing salaries or other staff expenses. Williamson (1963) reports that the management may increase "staff expenditures, managerial emoluments and discretionary profits" rather than focus strictly on maximizing profits. If the management prefers a greater number of staff or more locations, this is normally reflected in the short term in higher efficiency ratios. Such decisions may contribute to profitability in the long-run and this is exactly so in the case of the listed banks in Ghana.

\subsection{Economies of Scale Theory}

Emery (1971) \& Vernon (1971) were among the earliest researchers to link bank size with profitability (Haron \& Azmi, 2004). The economies of scale states that a bank with larger size could enjoy the economies of scale and produce services at lower cost per unit. Since large banks are assumed to enjoy the economies of scale, they are able to produce their outputs or services more cheaply and efficiently than can the small banks. As a result, large banks will earn a higher profit than small banks. It is expected, therefore, that bank size is positively related to bank profitability. The Structure-Conduct-Performance, Relative Market Power, Efficient-Structure and Expense-Preference Behaviors are theories widely used in the empirical studies such as Haron (2004) and Aimanaseer (2007) dedicated to bank profitability. Based on the framework of these theories, many studies have been done, but a lot of researchers do not restrict themselves into using only the internal and structure variables as the possible explanatory variables of bank profitability. Economies of scale are the various advantages that banks enjoy for operating on a large scale and as a result the per unit cost of operation is low. This assertion cannot be under estimated in assessing the performance of listed banks in Ghana is concerned. This theory is an epitome of this study, for this reason study has no excuse or whatsoever for not adopting the economies of scale theory as one of the vital theories underpinning this study.

\subsection{Empirical Review of Literature}

Okyinyi (2012) conducted a study to assess the performance of listed banks in Kenya. The study revealed that banks in Kenya seem to be earning much higher returns despite being in the same environment.

Sarpong, Winful and Owusu-Mensah (2014) conducted a study to assess the performance of commercial banks using accounting ratios. The study found that all the banks maintained sufficient capitalization but were among the highest in terms asset deterioration in SubSaharan Africa. Sarkodie, Addai and Asiedu (2015) urged micro finance institutions to 
pay particular attention to their current, acid test and debt ratios.

Naser (2013) conducted a study to find out the financial performance of banks in Bahrain. The study revealed that there is a relation between asset management and value of equity shares. The study also revealed that financial ratios could predict the future of banks. Finch (2015) indicated that one of the frequently used analytical tools for managerial decision making is financial ratios. The author mentioned that financial ratios compare different numbers from the financial statements of a firm so that data from its performance could be ascertained.

Bashir (2001) assessed the relationship between the financial performance and the banks' characteristics. The study revealed the empirical role that sufficient capital ratios and loan portfolios play in determining the financial performance of Islamic banks. Factors such as non-interest earning assets and customer and short-term financing, contribute to the rise of the Islamic banks' profit. The study controlled for macroeconomic environment, financial market situation and the effect of taxation, the results indicate that higher financial leverage and significant loans to asset ratios, result in higher profitability. The study again, posited that foreign-owned financial institutions are more profitable the local firms.

Hassan and Bashir (2003) examine the determinants of Islamic bank performance and the findings indicate that for Islamic banks to be efficient as conventional banks if one uses standard accounting measure such as cost to income ratio. Moreover, banks should have adequate knowledge of how to manage their data and how to create and amend the database periodically.

Samad \& Hasan (1999) employed financial ratio to analyse the performance of Malaysian Islamic banks over the period 1984-1997. It was found that there was lack of knowledge of the banks which resulted in the slow growth of loans under profit sharing.

Samad (2004) examined the performance of commercial banks in Bahrain taken into consideration liquidity, credit and profitability. The study used ten financial ratios to assess credit, liquidity and profitability performances. The t-test results indicated that the liquidity performance of commercial banks was not the same with the banking industry average. Tarawneh (2006) established that if a bank's total capital, deposits, credits, or total assets are high, it does not always mean better profitability performance. The size and operational efficiency of a bank have a positive relationship with the profitability banks. This study posits that operational efficiency, bank size and asset management have a positive effect on financial performance of the banks.

Jahangir et al., (2007) posited that the use of conventional indicators to measure differs from one bank to another or from one sector to another. Jahangir et al., (2007) opined that a good indicator to measure the profitability of a bank is loan-to-deposit ratio. Kumbirai and Webb (2010) also mentioned that that accounting ratios are employed to measure the liquidity, credit quality and profitability of a bank.

Abdulrahman and Al-Sabaawee (2011) employed financial analysis and financial ratios in a study to assess the performance of Islamic banks. The study indicated that financial ratios 


\section{MlMacrothink}

International Journal of Accounting and Financial Reporting

ISSN 2162-3082

2020, Vol. 10, No. 1

have positive influence on financial performance of Islamic banks. Almazari (2011) also used accounting ratios to assess the operational efficiency of commercial banks in Jordan. The study revealed that banks with higher total deposits, credits, assets, and shareholders' equity do not always mean better profitability performance. The results also showed that there is positive relationship between financial performance and asset utilization, asset size, and operational efficiency.

Sidqqui and Shoaib, (2011) concluded in their study "Measuring performance through capital structure in Pakistan" that size of the bank plays an important role in determining the profitability of the bank using ROE as profitability measure. In addition, Tobin's Q model was also used in the study to measure banks profitability and performance and found direct and positive relation with the size of the banks, the leverage ratio and Investments by banks in assets.

Almumani (2014) conducted a study using accounting ratios to analyze and compare the performance Saudi banks listed for the period 2007-2011. The study revealed that if assets, operating expenses and cost to income increase, profit will also decrease whilst increase in operating income will result in increase in profitability of the banks of Saudi Banks.

\subsection{Performance of Profitability}

Return on asset, return on equity, net interest margin and return on deposit are common accounting ratios used to measure profitability in the banking. These ratios are explained below:

\subsubsection{Return on Assets (ROA)}

Bodie et al. (2009) mentioned that return on assets relate to the income earned by the bank to the assets it used in the business operation. It is commonly defined as net income (or pre-tax profit)/total assets. It provides information about management's performance in using the assets of the business to generate income. Profit before tax is generally ideal because calculations using net income after tax figures may show trends due simply to changes in the rates of taxation

\subsubsection{Return on Deposits (ROD)}

Khrawish (2011) stated that return on deposit is calculated through dividing net profits by total deposits. It clearly shows the extent to which the overall return on deposit ratios fluctuates through the period for the bank. To most financial analysts, return on deposit is one of the best measures of bank profitability performance. This ratio reflects the bank management ability to utilize the customers' deposits in order to generate profits (Wen, 2010).

\subsubsection{Return of Equity (ROE)}

Khrawish (2011) indicated that ROE measures the profitability of an entity. It measure how much profit an entity generates with the shareholders' invested capital. If ROE is higher, it indicates that the bank is performing efficiently with regard to profitability of a bank. 


\subsubsection{Net Interest Margin (NIM)}

Gul et al. (2011) indicated that net interest margin (NIM) is a ratio which measures the difference between the interest income and the amount of interest paid out to lenders. This ratio is usually expressed as a percentage of interest on loans in a stipulated period of time.

\subsection{Liquidity Performance}

Liquidity ratios indicate the ability of the bank to meet its short-term financial obligations. These ratios are considered to be higher if the banks are operating in margins of safety. This means that the bank will be able to honour their short-term financial obligations. The following ratios fall under liquidity ratios:

\subsubsection{Total Loans to Total Deposits Ratio (TL/TD)}

Rudolf (2009) indicated that total loans to total deposits ratio is a commonly used measure for assessing liquidity and credit risk, which measured by dividing the banks total loans or total financing by its total deposits. This ratio indicates, however, the percentage of a bank's loans funded through deposits. On the other hand, a high loan to deposit ratio may indicate several things, but from liquidity's viewpoint, a high value of such ratio indicates a potential source of illiquidity and insolvency due to deposits are quite stable source of funding for a bank and loans are riskier asset than other financial assets because of lower market liquidity. Therefore, a higher loan deposit ratio means more financial stress by making excessive loans. So, the lower loan deposit ratio is always favourable to the higher one

\subsubsection{Total Deposits to Total Assets Ratio (TD/TA)}

Rudolf (2009) mentioned that the ratio of total deposits to total assets is another liquidity measure, which considered a traditional liquidity. This ratio is measured by dividing the banks total loans or total financing by its total assets. However, such ratio indicates the broad "reliable" base of funding for the bank, which establishes how much of the bank's assets are funded by deposits, rather than borrowed funds or equity.

\subsubsection{Assets Quality (Credit Performance)}

Casu et al. (2006) have indicated that credit is considered as one of the most essential activities of a bank. Bank managers are supposed to manage their credit very well in order to avoid loan default. Bad loans and loan losses affect the continuity of banks.

\subsubsection{Financial Leverage (Capital Adequacy)}

Assessment of Capital adequacy requirement is to ensure that banks hold sufficient resources to absorb shocks to their balance sheets. It is designed to assess the solvency of banks. The requirement protects the banks' depositors and lenders and also maintains confidence in the banking system. It is used to measure leverage and assess whether the banks are prepared to take greater risk. If the capital adequacy ratio is higher, then the leverage too is lower. It is designed to gauge the banks' solvency. A ratio below regulators required minimum implies that the bank is not adequately capitalized to expand its operations. Capital structure (Leverage) can be calculated by the total debt divided by total Equity plus total debts 


\section{$\Lambda$ Macrothink}

(Bergrren \& Bergqvist, 2014). This can be represented algebraically as follows:

$$
\text { FINLEV }_{i, t}=\frac{\text { TDebt }_{i, t}}{T E_{i, t}+T D e b t_{i, t}}
$$

Where:

TDebt $_{i, t}$ represent the total debt of bank $i$ in the year $t$

$T E_{i, t}$ represent the total equity of bank $i$ in the year $t$

\subsection{Performance}

Performance refers to the role played by an arrangement keeping in view the achievement made by it. In the context of the banks, it takes into account the way of their progress (Nirmal, 2004). Chan et al. (2004) described performance as the efforts extended to achieve the targets efficiently and effectively, the achievement of targets involves the integrated use of human, financial and natural resources.

\subsubsection{Financial Performance}

Financial performance is the process of measuring the results of an organization policies and operations in terms of monetary value. These results are reflected in the firm's profitability, liquidity or leverage. Evaluating the financial performance of a business allows decision-makers to judge the results of business strategies and activities in objective monetary terms. Normally the ratios are used to determine the financial performance of an organization. A well designed and implemented financial management is expected to contribute positively to the creation of a firm's value (Padachi, 2006). Ultimate goal of profitability of a firm can be achieved by efficient use of resources. It is concerned with maximization of shareholders or owners' wealth (Panwala, 2009).

Bank financial performance evaluation is traditionally based on the analysis of financial ratios such return on equity (ROE), return on assets (ROA), net interest margin (NIM), capital asset ratio, growth rate of total revenue, cost/income ratio. However, regardless of how many ratios are being used, a model that would fully satisfy the analysis of needs and bank operations' efficiency evaluation has not been developed yet. For this reason, the financial ratio analysis is complemented with different quality evaluations, with features such as management quality, equity structure, competitive position and others to be included into the final evaluation (Tihomir, 2001).

Medhat (2006) evaluated the financial performance of Omani Commercial banks. The study used multiple regression analysis and correlations by employing ROA and interest income as performance proxies which represented as the dependent variables, and bank size, asset management and operational efficiency as independent variables. The study found that there is strong positive correlation between financial performance and operational efficiency and a moderate correlation between ROA and bank size, while, ANOVA analysis; results indicated 
that, there exists an impact of those independent variables on financial performance as the F-stat was significant and below the $5 \%$.

Ahmad (2011) investigated the financial performance of seven Jordanian commercial banks; the study used ROA as a measure of banks' financial performance and the bank size, asset management and operational efficiency as three independent variables affecting the financial performance. The results of the study showed a strong negative correlation between ROA and banks' size, a strong positive correlation between ROA and asset management ratio, and a negative weak correlation between ROA and operational efficiency.

Khizer at el., (2011) study about banks' profitability in Pakistan, they found a significant relation between asset management ratios, capital and economic growth and with ROA, the operating efficiency, asset management and economic growth are significant with the ROE. On the other hand, domestic banks are determined to have a lesser capital adequacy ratio than foreign banks.

Chiaku at el., (2006) examined the comparative performance of small U.S. commercial banks, medium size commercial banks and large commercial banks for the period of 1997-2002 by employing profit efficiency (PROFEFF), return-on-assets (ROA), interest income, non-interest income and loan loss reserve as criteria for the comparison. The results showed that between 1997 and 1999, small banks were more profit efficient (PROFEFF) than large banks but less than medium- size banks.

Abdus at el., (2006) evaluated the inter-temporal performance of commercial banks; the study was based on three categories of bank size, large, medium and small banks in the State of Utah for the period of 5 years from 2000 to 2004, by using two measures of performance profits and quality of loans. T-tests and Kruskal-Wallis tests were applied to a variety of standard bank operations measures to determine whether there are significant differences in performance among the three categories of banks. The performance measures used were return on assets (ROA), return on equity (ROE), loan loss reserve ratio, and loans past due 30-89 days as a percentage of total loans. The study results showed that, no significant difference in performance between small and large banks between the years 2000 and 2004. However, there was a significant difference between small and medium, and medium and large banks in their ROA; the ROA of medium banks is significantly higher than that of small and large banks.

Sanaullah (2009) compared the financial performance of Islamic and Conventional banks in Pakistan from 2006 to 2009 by employing Independent sample t-test and ANOVA to determine the significance of mean differences of financial ratios between and among banks, eighteen financial ratios were estimated to measure the performances in term of profitability, liquidity, risk and solvency, capital adequacy, deployment and operational efficiency. The results of the study indicated that, Islamic banks proved to be more liquid, less risky and operationally efficient than conventional banks.

\section{Research Design}

Research design is the blueprint or detailed outline for the whole research. Aggyemang and 


\section{Mll Macrothink}

International Journal of Accounting and Financial Reporting

ISSN 2162-3082

2020, Vol. 10, No. 1

Yensu (2018) referred to research design as a mapping strategy that is based on sampling technique. It essentially includes objectives, sampling, research strategy, tools and techniques for collecting the evidences, analyzing the data and reporting the findings. Saunders et al (2009) also stated that, there are three categories of research design: exploratory, descriptive and explanatory (or causal). They indicated that research design allows the researcher to meet the purpose of the research as the overall plan employed in relation to philosophies, approaches, strategies, choices, techniques and procedures to obtain answers to research questions. This study adopted a descriptor-exploratory method. This method assesses the financial performance of listed banks on the Ghana stock exchange. The study starts with descriptive research and later follows with exploratory research. In conducting such descriptive study, the deductive research philosophy is applicable as an overall "top-down" approach. By using relevant theoretical rationales, it has been sought to deduct clear conclusions emphasizing validity of the results as a success criterion (Gray, 2009).

\subsection{Population of the Study}

Agyemang, Wingard and Acheampong (2019) referred to population as the total group of items, individuals, objects or events showing common characteristics. population is the total collection of elements about which we wish to make some inferences. A population is the subject of which the measurement is being taken. For the purpose of this research, the population comprises all listed banks on the Ghana Stock Exchange.

\subsection{Sample and Sampling Technique}

Existing and accurate databases in Ghana for research purposes have always been a challenge for developing an appropriate sample frame (Boso et al., 2013). Purposive sampling technique was used to select the listed banks. This is because only listed banks have been sampled and also listed banks whose financial reports have not been audited for the study period were excluded. Non availability of data for some banks has limited the sample size to six banks.

\subsection{Variables and Their Measurement}

\begin{tabular}{llll}
\hline Variable & Description & Measurement & Source \\
\hline ROA & Return on Assets & Net Income divided by total Assets & $\begin{array}{l}\text { Bodie et al., } \\
(2009) .\end{array}$ \\
\hline ROE & Return on Equity & $\begin{array}{l}\text { Net Income divided by } \\
\text { shareholders Equity }\end{array}$ & $\begin{array}{l}\text { Khrawish, } \\
(2011)\end{array}$ \\
\hline
\end{tabular}

ROD Return on Deposit $\begin{aligned} & \text { Net Income divided by total Wen, (2010) } \\ & \text { deposits }\end{aligned}$

NIM Net Interest margin net interest income divided by total Gul et al., 
earnings assets

(2011).

\begin{tabular}{|c|c|c|c|}
\hline TL/TD & $\begin{array}{l}\text { Total Loans to Total } \\
\text { Deposit Ratio }\end{array}$ & $\begin{array}{l}\text { Total Loans divided by total } \\
\text { deposits }\end{array}$ & Rudolf, (2009) \\
\hline TD/TA & $\begin{array}{l}\text { Total Deposit to } \\
\text { Assets Ratio }\end{array}$ & $\begin{array}{l}\text { Total Deposit divided by total } \\
\text { Assets }\end{array}$ & Rudolf, (2009) \\
\hline FINLEV & Financial Leverage & $\begin{array}{l}\text { Total debts divided by the sum of } \\
\text { total debts and equity }\end{array}$ & $\begin{array}{l}\text { Bergrren } \\
\text { Bergqvist } \\
(2014) \text {. }\end{array}$ \\
\hline CPERF & Credit performance & $\begin{array}{l}\text { Provision for bad loan divided by } \\
\text { total loan for the year }\end{array}$ & $\begin{array}{l}\text { Demirguc-Kunt } \\
\text { et al., (2000). }\end{array}$ \\
\hline
\end{tabular}

Source: Researchers, 2019

\subsection{Data Analysis}

Descriptive and inferential Statistical tools were used to aid the analysis. Means and standard deviations were analyzed under the descriptive statistics for all variables under consideration. Again, whereas vertical bar charts would be used to analyze profitability, credit performance and capital adequacy ratio, line charts were adopted to analyze the liquidity ratios of the listed banks based on the objectives and the hypotheses developed, and Conclusions would be drawn from the analyses of the results derived from the charts.

\section{Findings, Analysis and Discussions}

\subsection{Descriptive Statistics}

The diagram below shows the mean, minimum, maximum and standard deviation values of the variables comprising return on asset, return on equity, return on deposit, net interest margin, total deposit to total asset, total loan to total deposit, credit performance and financial leverage. The mean is a measure of central tendency and effectively gives values that typify the sampled data consisting of 6 listed banks for the purpose of this research. It is an average statistic despite the differences in strength of individual values in respect of the various banks. The mean values of return on asset, return on equity, return deposit, net interest margin and financial leverage are $3.48,22.23,20.97,8.18$ and 8.03 respectively and with their respective standard deviations of 1.62, 10.25, 25.44, 3.67 and 3.99. Again, the mean values and standard deviations of total loan to total deposit, total deposit to total asset and credit performance are $52.20,67.42,16.21$ and $32.20,16.59,11.36$ respectively and this is presented in Table 1 below. 
Table 1. Descriptive statistics

\begin{tabular}{llllll}
\hline Variable & $\mathrm{N}$ & Minimum & Maximum & Mean & Std. Deviation \\
\hline Return on Asset & 28 & 1.13 & 7.00 & 3.48 & 1.62 \\
\hline Return on Deposit & 28 & 6.74 & 77.00 & 20.97 & 25.44 \\
\hline Return on Equity & 28 & 4.14 & 44.00 & 22.23 & 10.25 \\
\hline Net Interest Margin & 28 & 2.98 & 18.00 & 8.18 & 3.67 \\
\hline Total Loan to Total Deposit & 28 & 10.26 & 113.00 & 52.20 & 32.20 \\
\hline Total deposit to Total Asset & 28 & 5.00 & 100.00 & 67.42 & 16.59 \\
\hline Financial Leverage & 28 & 4.94 & 20.00 & 8.03 & 3.99 \\
\hline Credit Performance & 28 & 4.81 & 45.00 & 16.21 & 11.36 \\
\hline Valid N (listwise) & 28 & & & & \\
\hline
\end{tabular}

Source: researchers, 2019

\subsection{Examining Financial Performance (Profitability)}

In examining the financial performance of the listed banks in Ghana, financial ratios were computed, and vertical bar charts were used for the analysis. Four important and key financial ratios as measures for financial performance used were return on asset, return on equity, return on deposit and net interest margin. Below are the detailed discussions on these ratios and the results presented in bar charts

\subsubsection{Return on Asset (ROA)}

In measuring the efficiency of banks in terms of their ability to use assets in maximizing profit, return on asset was computed and analysed. It was therefore revealed that among all the listed banks Ghana commercial bank (GCB) experienced the worst performance in the year 2015 with less than $1 \%$ but rose to be the best for the year 2016 with $7 \%$ which was at par with Ecobank (ECOB) but for 2015 and Republic Bank (REPUB) trailing below the Ghana industry average (GHINDA). This finding is in agreement with (Kumbirai \& Webb 2010). The performance of GCB decreases steadily to $3 \%$. It was also evident that not only GCB falls below the GHINDA but also ECOB having 3\% for year 2015. The general performance of the banks dwindled in 2017, with CAL Bank (CALB), ECOB and Standard Chartered Bank (STANB) all having $4 \%$ which is above the GHINDA of $3 \%$ whilst Access Bank (ACCES) and REPUB performing below the GHINDA with ROA of $2 \%$ and $1 \%$ 


\section{Macrothink}

respectively. The overall performance of REPUB is poor as a result always trailing below GHINDA, conversely, the general performance of ECOB and STANB was very good this is indicated in the Figure1 below.

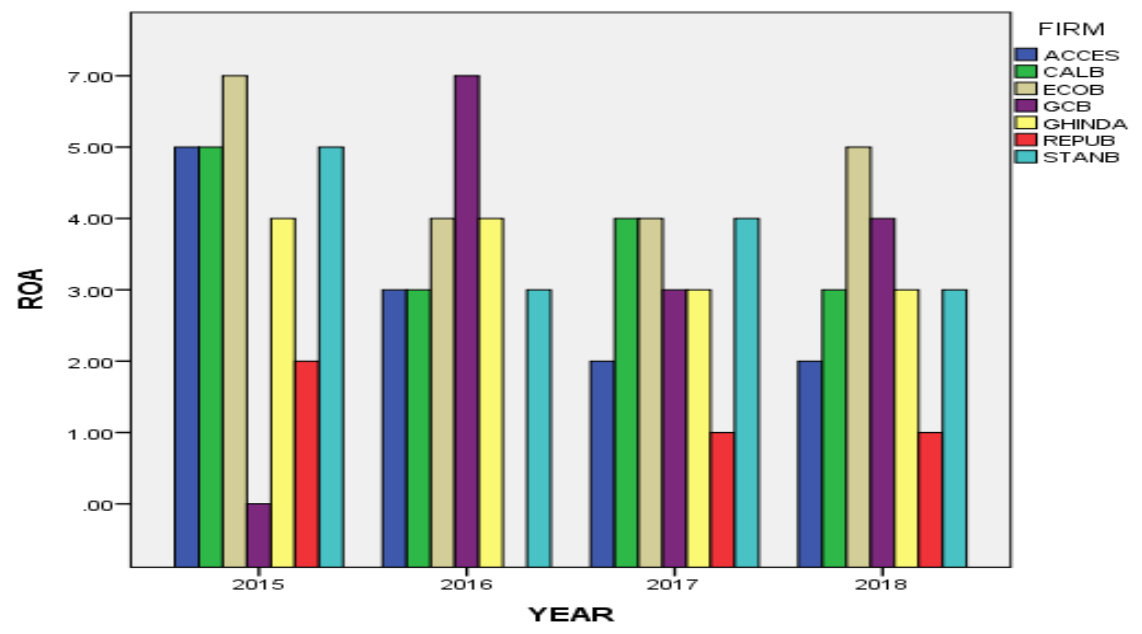

Figure 1. Return on asset

Source: researchers, 2019

\subsubsection{Return on Equity (ROE)}

Return on equity measures a corporation's profitability by revealing how much profit a company generates with the money shareholders have invested. The higher such ratio, the more efficient is the financial performance of profitability of a bank. Such profitability ratios measure the financial performance and the managerial efficiency of banks. However, profitability ratios are only part of bank performance story (Khrawish, 2011). The chart below indicates the return on equity for the listed banks for the years 2015, 2016, 2017 and 2018. In 2015 ACCES experienced the highest performance followed closely by CALB and STANB with $34 \%, 32 \%$ and $32 \%$ respectively which is above the $22.12 \%$ GHINDA. On the other hand, GCB, ECOB and REPUB performed below the GHINDA with ROE of $0.001 \%, 9 \%$ and $21 \%$ respectively. The performance in 2016 was quite surprising with GCB emerging as the highest closely followed by ECOB, CALB and STANB also followed suite with ROE of $44 \%, 35 \%, 20 \%$ and 20\% respectively. Again, the performance in 2017 was not different with the exception of ACCES appearing below the GHINDA. The performance in 2018 by the banks has seen some improvement but ACCES and REPUB have still trailed behind the GHINDA. It is also clear that the performances of ECOB and GCB have been consistent and encouraging especially in the fiscal years 2016, 2017 and 2018. 


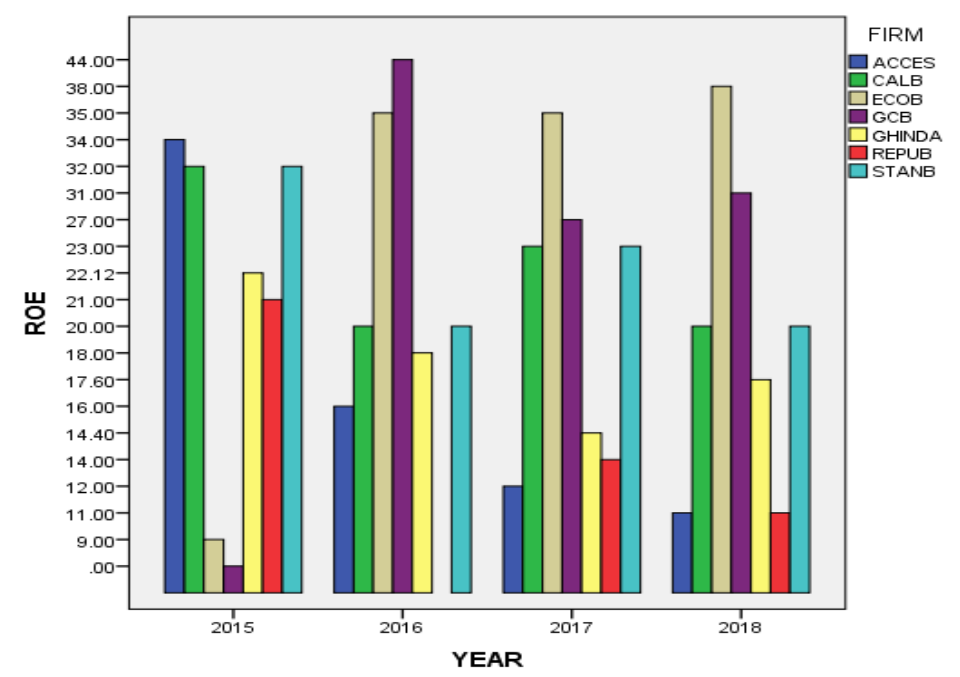

Figure 2. Return on equity

Source: Researchers, 2019

\subsubsection{Return on Deposit (ROD)}

Chart 4.3 shows that the returns on deposits (ROD) of the listed banks are not encouraging. It is clearly shown that overall (ROD) ratios for years under review fluctuated throughout the period under study. To most financial economists and analysts, (ROD) is one of the best measures of bank profitability performance. It is calculated by dividing net profits by total deposits. This ratio reflects the bank management ability to utilize the customers' deposits in order to generate profits. Unfortunately, only ECOB has performed above the GHINDA for the 2015 fiscal year and in 2016 all the banks failed to meet the GHINDA benchmark. However, in 2017 and 2018 CALB and STANB outperformed the GHINDA with ROD of $74 \%, 74 \%$ and $77 \%, 77 \%$ respectively.

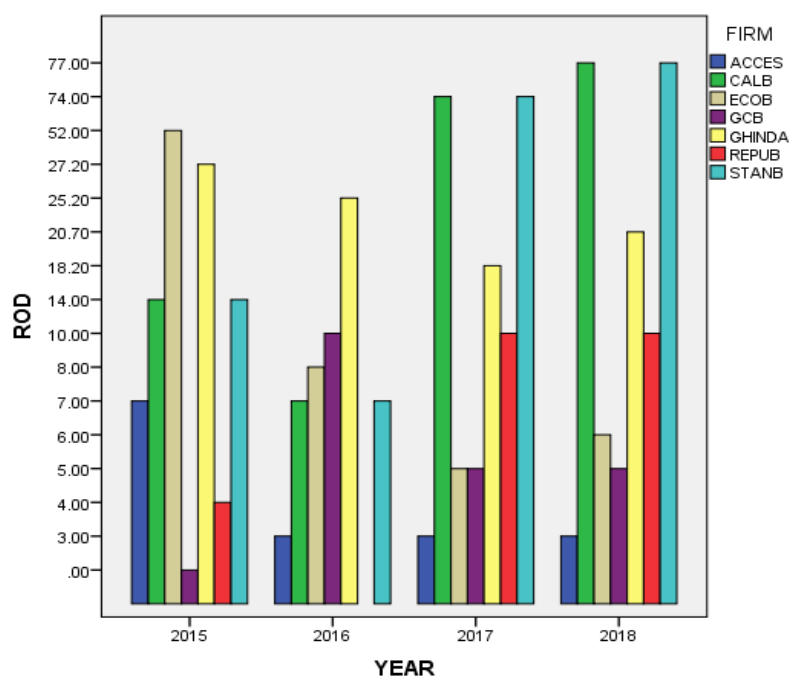

Figure 3. Return on deposit

Source: researcher 2019 


\section{Macrothink \\ International Journal of Accounting and Financial Reporting \\ ISSN 2162-3082 \\ 2020, Vol. 10, No. 1}

\subsubsection{Net Interest Margin (NIM)}

Net Interest Margin (NIM) is a measure of the difference between the interest income generated by banks and the amount of interest paid out to their lenders (for example, deposits), relative to the amount of their (interest earning) assets. All the banks have performed abysmally for the fiscal years 2015, 2016 and 2017 with all of them trailing below the GHINDA. However, the 2018 fiscal year has seen a dramatic turnaround with all the banks performing above the GHINDA with the exception of REPUB which is below the GHINDA. The chart below depicts this assessment.

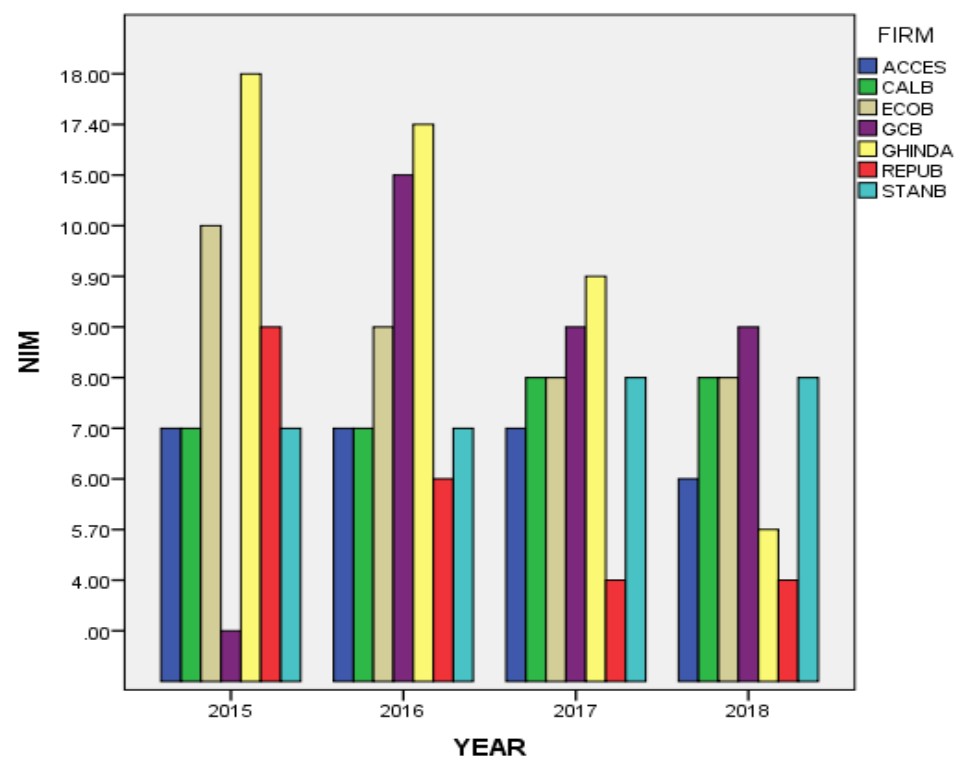

Figure 4. Net interest margin

Source: researchers 2019

\subsection{Assessing the Liquidity Performance of the Listed Banks}

Liquidity ratios in a bank demonstrate the ability to pay its current obligations. Generally, the higher the value of the ratio, the larger the margin of safety that a bank possesses to cover short-term obligations. In evaluating the liquidity performance of the banks two key ratios were computed and analysed using vertical bar charts, viz Total deposit to Total Asset (TD/TA) and Total Loan to Total Deposit (TL/TD)

\subsubsection{Total Deposit to Total Asset (TD/TA)}

The ratio of total deposits to total assets is another liquidity measure, which considered a traditional liquidity, such ratio indicates the broad "reliable" base of funding for the banks, which establishes how much of the bank's assets are funded by deposits, rather than borrowed funds or equity (Rudolf, 2009). The chart below epitomises the fact that the asset base of most banks in Ghana is small. Again, in assessing the liquidity performance of the banks it was revealed that only STANB, CALB and REPUB have better liquidity position with their respective ratios of $48 \%, 48 \%$ and $59 \%$, and as a result lie below GHINDA in the fiscal year 
2015. Interestingly, STANB, ECOB and GCB performed quite abysmally as shown in Figure 5 below.

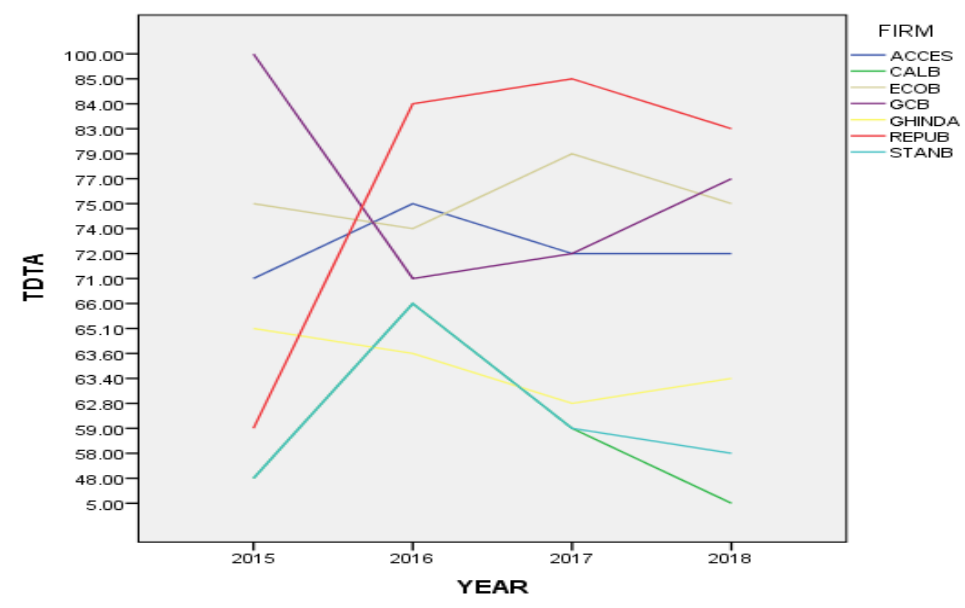

Figure 5. Total deposit to total asset

Source: Researchers, 2019

\subsubsection{Total Loan to Total Deposit (TL/TD)}

This ratio is a commonly used measure for assessing liquidity and credit risk. The most liquid bank in 2015 is GCB with the least liquidity ratio and lies below the GHINDA. Contrary, ECOB, ACCES, REPUB, STANB and CALB have high credit risk with CALB emerging as the most insolvent bank with their respective TL/TD 63\%, 69\%, 100\%, 112\% and 113\%. This problem could be associated with intensification of regulation by bank of Ghana in recent time of the banking sector in Ghana. Even though there is improvement in the performance of these banks in recent years on REPUB lies blow the GHINDA.

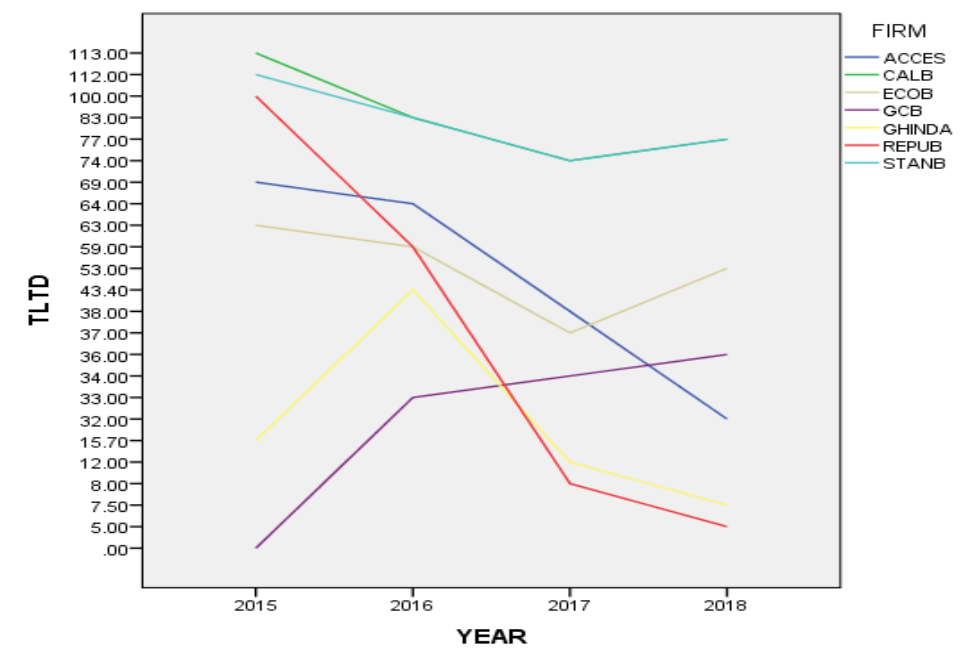

Figure 6. Total to total deposit

Source: researcher, 2019 


\subsection{Assessing Credit Performance of Listed Banks in Ghana}

Lending is still one of the most important activities of banks. Credit performance is calculated as provision for bad loans divided by total loans. It is inevitable for banks to recover $100 \%$ of loans lent to its customers. It measures the banks' capability in ensuring that loans together with their principal are collected. Lower ratio indicates better asset quality. While it is expected that all banks will have to bear some positive level of bad loans and loan losses; one of the key objective of bank management is to minimise such losses (Casu et al., 2006). Out of the six listed banks under study only ACCES has performed beyond expectation for almost all the four years under consideration attaining less than $1 \%$ throughout the fiscal years and followed by CALB which also achieved 6\%,8\%,11\% and slightly declined (improved) to 8\%, for the years 2015, 2016, 2017 and 2018 respectively. Conversely, the STANB experienced worst performance among all the banks for all the years with the results $43 \%, 45 \%, 35 \%$ and $25 \%$, respectively. It was also evident that, the performance of ECOB has not been consistent with the Results18\%, 12\%, 20\% and 12\% respectively as shown in Figure 7 below.

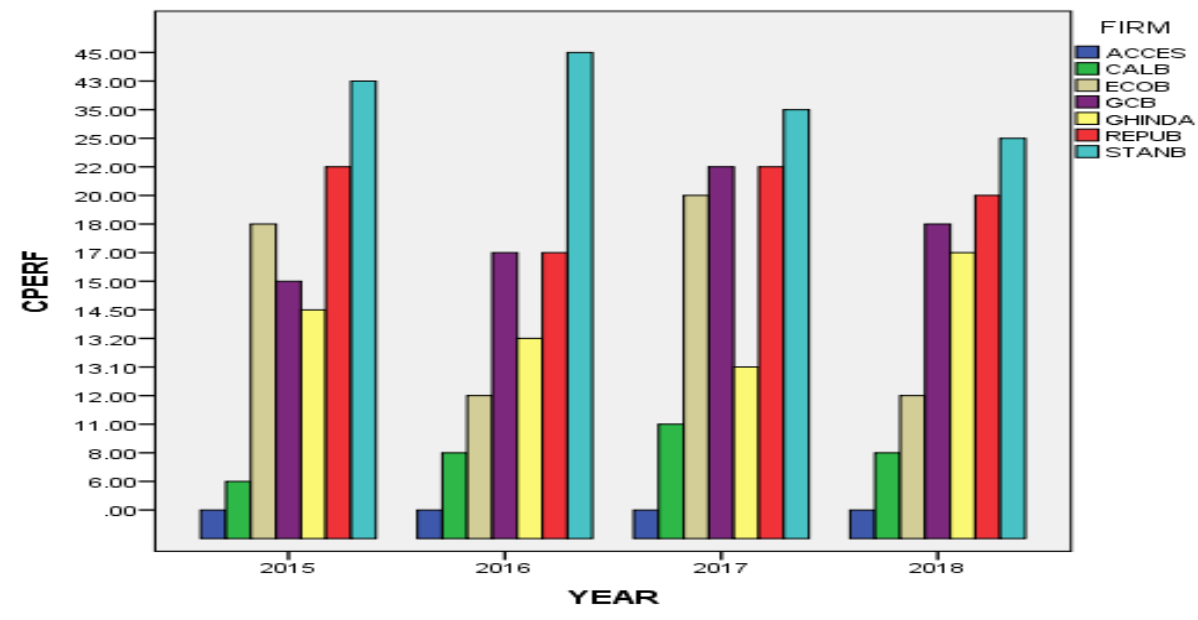

Figure 7. Credit performance

Source: researchers, 2019

\subsection{Examining the Capital Structure of Listed Banks in Ghana}

Capital structure which is also known as capital adequacy requirement is to ensure that banks hold sufficient resources to absorb shocks to their balance sheets. It is designed to assess the solvency of banks. The requirement protects the banks' depositors and lenders and also maintains confidence in the banking system. It is used to measure leverage and assess whether the banks are prepared to take greater risk. The higher the capital adequacy ratio, the lower the leverage. It is designed to gauge the banks' solvency. A ratio below regulators required minimum implies that the bank is not adequately capitalized to expand its operations. The chart below shows the level of financial leverage or the capital adequacy ratio of the listed banks in Ghana. This revealed the highly inadequate capital or equity component of capital of the listed banks. The recent effort by the Bank of Ghana (BoG) for intensifying its 
bank regulations to recapitalise their capital structure epitomises the worrying insufficient capital by the listed banks. The GCB is the best capitalised banks for 2015 and 2016 fiscal year with FINLEV $82.38 \%$ and $83.17 \%$ but rose drastically 2017 and declined gradually in 2018 and may be attributed to the takeover of some banks by GCB as a result of low capitalisation.

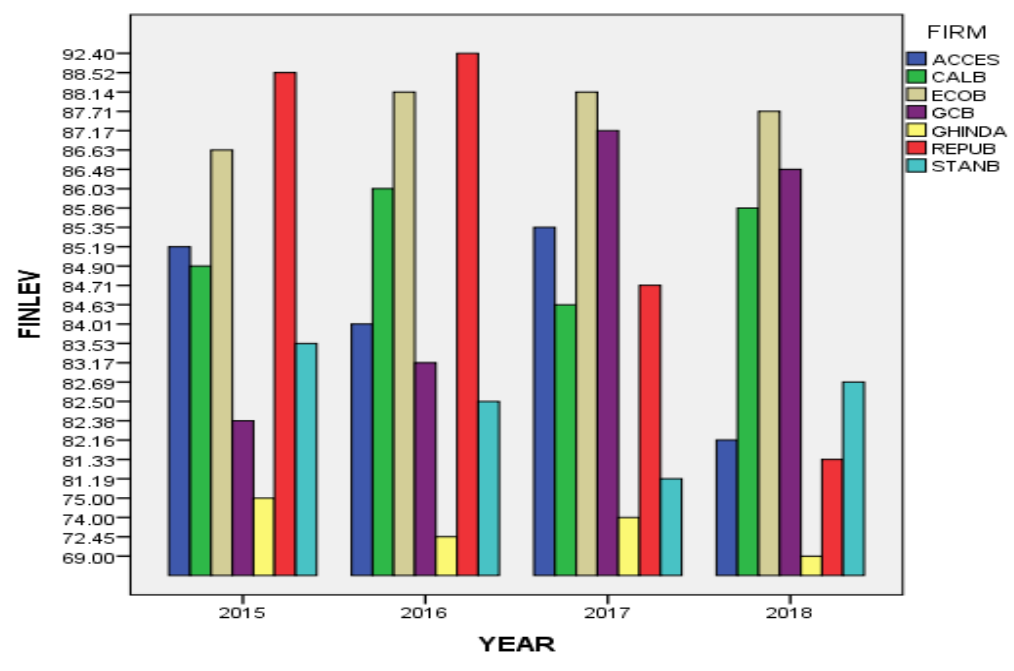

Figure 8. Assessing the capital structure of listed banks

Source: researchers, 2019

\subsection{Discussion of Results}

The findings from this study are inconsistent with that of Abdus at el., (2006). The authors evaluated the inter-temporal performance of commercial banks; the study was based on three categories of bank size, large, medium and small banks in the State of Utah, using two measures of performance - profits and quality of loans. The performance measures used were return on assets (ROA), return on equity (ROE), loan loss reserve ratio, and loans which were more than their maturity time of settlement.

The results from this study support Ahmad (2011). The author investigated the financial performance of seven Jordanian commercial banks using ROA as a measure of banks' financial performance and the bank size, asset management and operational efficiency as three independent variables affecting the financial performance. The results of the study showed a strong negative correlation between ROA and banks' size, a strong positive correlation between ROA and asset management ratio, and a negative weak correlation between ROA and operational efficiency.

The results from the current study also support Khizer at el., (2011). The authors investigated about banks' profitability in Pakistan. The study found that a significant relation between asset management ratios, capital and economic growth and with ROA, the operating efficiency, asset management and economic growth are significant with the ROE. On the other hand, domestic banks are determined to have a lesser capital adequacy ratio than foreign banks. Again, in investigating the liquidity performance of the banks the study 
revealed that most the banks have liquidity challenges and this finding is conformity with the findings of Appiah et al., (2017). They posited that most of the banks and financial institutions in Ghana have liquidity issues when they investigated credit risks assessment of the listed banks in Ghana

\subsection{Conclusions}

From the analysis and findings, it was very imperative to investigate and evaluate the financial performance of the listed banks in Ghana. Most of the banks were not cost efficient and were not efficient in generating profits from the use of assets. The banks generated relatively lower returns to shareholders on their investments. This could be attributed to poor asset quality, underutilization of assets. It may also be due to management's inability to implement measures which will ensure improvements in the utilization of assets. The banks were inefficient in improving asset quality. The banks had high nonperforming loans, resulting in poor asset quality. This shows that the banks have ineffective credit assessments and monitoring mechanisms. The banks however have low financial leverage and inadequately capitalized to expand its operations. Generally, the banks maintained low liquidity over the years. Some banks were comparatively efficient in their assets utilization, but this did not result in high profits for shareholders investments due to inadequate capitalization.

\subsection{Recommendations}

The importance of the findings from the study with regards to the management policy formulators and future researchers cannot be over emphasized.

\subsubsection{Managerial Implication}

Managers must efficient and effective utilization of resources to maximize profitability Again, managers must pay critical attention to lending policies to reduce bad loans or non-performing loans. Thus, ensuring effective assessment monitoring

\subsubsection{Policy Recommendation}

The central bank and other regulatory bodies should intensify their regulations to protect and safeguard the funds of customers and depositors such as minimum capital requirement and good corporate governance practices.

\subsubsection{Future Research Direction}

In assessing the financial performance of the listed banks in Ghana, the study used panel data for the analyses. The researchers therefore recommend that: future studies should extend the study beyond Ghana to assess the consistency or otherwise of these findings, use primary data to investigate and assess the financial performance of either the listed banks or non-listed banks is would be a ground-breaking study for academicians.

\section{References}

Access Bank PLC. (2019). Corporate profile. Retrieved from www.ghana.accessbankplc.com 
Adam, M. H. M. (2014). Evaluating The Financial Performance of Banks Using Financial Ratios-A Case Study of Erbil Bank for Investment And Finance. European Journal of Accounting Auditing and Finance Research, 2(6), 162-177.

Agyemang, J. K., \& Yensu, J. (2018). Accrual-Based International Public Sector Accounting Standards: Implementation Challenges Facing the Metropolitan, Municipal and District Assemblies in the Ashanti Region of Ghana. International Journal of Accounting and Financial Reporting.

Agyemang, J. K., Wingard, C. H., \& Acheampong, O. (2019). Fair Value Accounting in the Agricultural Sector: The Analysis of Economic and Educational Factors. Asian Journal of Economics, Business and Accounting, 9(4), 1-13.

Almazari, A. A. (2011). Financial performance evaluation of some selected Jordanian commercial banks. International Research Journal of Finance and Economics, 68(8), 50-63.

Almumani, M. A. (2014). A Comparison of Financial Performance of Saudi Banks (2007-2011). Asian Journal of Research in Banking and Finance, 4(2), 200-213.

Alsamaree, A. H. A. (2017). Financial ratios and the performance of banks. Journal of Research in International Business and Management, 3(1).

Annor, E. S., \& Obeng, F. S. (2017). Impact of Credit Risk Management on the Profitability of Selected Commercial Banks Listed on the Ghana Stock Exchange. Journal of Economics, Management and Trade, 1-10.

Bank of Ghana. (2018). Annual report-2018. High street Accra. Retrieved from www.bog.com

Bashir, A. H. M. (1999). Risk and profitability measures in Islamic banks: The case of two Sudanese banks. Islamic Economic Studies, 6(2).

Berger, A. N., \& Mester, L. J. (1997). Inside the black box: What explains differences in the efficiencies of financial institutions?. Journal of Banking \& Finance, 21(7), 895-947.

Bodie, Z., Merton, R. C., \& Cleeton, D. L. (2009). Financial Economics (2nd ed.). Pearson Prentice Hall. New Jersey USA.

Boso, N., Story, V. M., \& Cadogan, J. W. (2013). Entrepreneurial orientation, market orientation, network ties, and performance: Study of entrepreneurial firms in a developing economy. Journal of Business Venturing, 28(6), 708-727.

Buigut, K., Soi, N., Koskei, I., \& Kibet, J. (2013). The effect of capital structure on share price on listed firms in Kenya. A case of energy listed firms. European Journal of Business and Management, 5(9), 29-34.

Calbank. (2019). Corporate profile. Retrieved from www.calbank.net

Casu, B., Girardone, C., \& Molyneux, P. (2006). Introduction to Banking (Vol. 10). Prentice Hall (Pearson Education Ltd.). 
Chan, W. S., Frankel, R., \& Kothari, S. P. (2004). Testing behavioral finance theories using trends and consistency in financial performance. Journal of Accounting and Economics, 38, 3-50.

Demirguc-Kunt, A., Detragiache, E., \& Tressel, T. (2006). Banking on the principles: Compliance with Basel Core Principles and bank soundness. The World Bank.

Ecobank Ltd. (2019). Bank profile. Lome - Togo. Retrieved from www.ecobank.com

Edem, D. B. (2017). Liquidity Management and Performance of Deposit Money Banks in Nigeria (1986-2011): An Investigation. International Journal of Economics, Finance and Management Sciences, 5(3), 146-161.

Ekinci, A. (2016). The effect of credit and market risk on bank performance: Evidence from Turkey. International Journal of Economics and Financial Issues, 6(2), 427-434.

Finch, H. (2015). Financial ratios. Retrieved February 25, 2019, from https://www.referenceforbusiness.com

Ghana Commercial Bank Ltd. (2019). Company profile. High street, Accra, Ghana. Retrieved from www.gcbbank.com.gh

Gilbert, R. A., \& Wheelock, D. C. (2007). Measuring commercial bank profitability: proceed with caution. Networks Financial Institute Working Paper (p. 22), 2007-WP.

Gul, S., Irshad, F., \& Zaman, K. (2011). Factors Affecting Bank Profitability in Pakistan. Romanian Economic Journal, 14(39).

Haque, I., \& Sharma, R. B. (2011). Benchmarking financial performance of Saudi banks using regression. International Journal of Business Economics and Management Research, 2(1), 78-84.

Harcourt, E. E. (2017). Credit risk management and performance of deposit money banks in Nigeria. International Journal of Managerial Studies and Research, 5(8), 47-57.

Jahangir, N., Shill, S., \& Haque, M. A. J. (2007). Examination of profitability in the context of Bangladesh banking industry. ABAC Journal, 27(2).

Kani, S. (2017). Credit risk and banks performance: Evidence from WAEMU countries. IOSR. Journal of Economics and Finance, 8(1), 5-11.

Kashyap, A. K., Rajan, R., \& Stein, J. C. (2002). Banks as liquidity providers: An explanation for the coexistence of lending and deposit-taking. The Journal of Finance, 57(1), 33-73.

Khrawish, H. A. (2011). Determinants of commercial banks performance: Evidence from Jordan. International Research Journal of Finance and Economics, 81, 148-159.

Kumbirai, M., \& Webb, R. (2010). A financial ratio analysis of commercial bank performance in South Africa. African Review of Economics and Finance, 2(1), 30-53.

Okyinyi, N. J. (2012). Performance and Financial Ratios of Commercial Banks in Kenya 


\section{I Macrothink}

International Journal of Accounting and Financial Reporting ISSN 2162-3082 2020, Vol. 10, No. 1

from 2006-2010. Unpublished master's thesis, University of Nairobi, Nairobi, Kenya.

Republic Bank Ghana Ltd. (2018). Company profile. Retrieved from www.republicghana.com

Samad, A. (2004). Bahrain commercial bank's performance during 1994-2001. Credit and Financial Management Review, 10(1), 33-40.

Sarkodie, E., Addai, I., \& Asiedu, D. (2015). Financial ratios (accounting ratios) and survival of Microfinance Institutions in Ghana. Journal of Business and Financial Affairs, 4(3), 1-3.

Sarpong, D., Winful, E., \& Owusu-Mensah, M. (2014). Assessing the performance of banks listed on Ghana Stock Exchange: Financial ratio analysis (2005-2011). Journal of Economics and International Finance, 6(7), 144-164.

Seiford, L. M., \& Zhu, J. (1999). Profitability and marketability of the top 55 US commercial banks. Management Science, 45(9), 1270-1288.

Shoaib, A. (2011). Measuring performance through capital structure: Evidence from banking sector of Pakistan. African Journal of Business Management, 5(5), 1871-1879.

Soteriou, A., \& Zenios, S. A. (1999). Operations, quality, and profitability provision of bank services. Management Science, 45(9), 1221-1238.

Standard Chartered Bank Ghana Ltd. (2017). Corporate profile. Retrieved from http://www.sc.com

\section{Copyright Disclaimer}

Copyright for this article is retained by the author(s), with first publication rights granted to the journal.

This is an open-access article distributed under the terms and conditions of the Creative Commons Attribution license (http://creativecommons.org/licenses/by/4.0/) 